\title{
Retraction: Novel two-stage surgical treatment for Cantrell syndrome complicated by severe pulmonary hypertension: a case report
}

\author{
Xiaochen $\mathrm{Wu}^{1}$, Jinbao Zhang ${ }^{1 *}$, Hui Ouyang ${ }^{1}$, Qin Yue ${ }^{1}$ and Heng Zhao ${ }^{2}$
}

\section{Retraction}

This article [1] has been retracted by the Editor. Although the patient's legal guardian originally gave consent for publication of the case and accompanying images, we were informed that they withdrew this consent shortly after publication. The article is no longer available online in order to protect patient confidentiality.

\section{Author details \\ 'Department of Cardiovascular, Chengdu Millitary General Hospital, 270th Rongdu Road, Chengdu City 610083, China. '2Department of Ultrasound, Chengdu Millitary General Hospital, 270th Rongdu Road, Chengdu City 610083, China.}

Received: 24 June 2013 Accepted: 27 January 2014

Published: 26 March 2014

\section{Reference}

1. Wu X, Zhang J, Ouyang H, Yue Q, Zhao H. Novel two-stage surgical treatment for Cantrell syndrome complicated by severe pulmonary hypertension: a case report. J Medical Case Reports 2014. 8:107.

\section{doi:10.1186/1752-1947-8-107}

Cite this article as: Wu et al: Retraction: Novel two-stage surgical treatment for Cantrell syndrome complicated by severe pulmonary hypertension: a case report. Journal of Medical Case Reports 2014 8:107.

\footnotetext{
* Correspondence: nowwilson@yeah.net

'Department of Cardiovascular, Chengdu Millitary General Hospital, 270th Rongdu Road, Chengdu City 610083, China

Full list of author information is available at the end of the article
}

Submit your next manuscript to BioMed Central and take full advantage of:

- Convenient online submission

- Thorough peer review

- No space constraints or color figure charges

- Immediate publication on acceptance

- Inclusion in PubMed, CAS, Scopus and Google Scholar

- Research which is freely available for redistribution

Submit your manuscript at www.biomedcentral.com/submit

( Biomed Central 